\title{
Autoritarismo, controle e vigilância: Jacob Gorender na mira da repressão (1940-1980)
}

\author{
Authoritarianism, control and vigilance: Jacob Gorender on \\ the aim of the repression (1940-1980)
}

\author{
Lucileide Costa Cardoso ${ }^{1}$
}

RESUMO

O propósito do artigo é demonstrar através da análise dos documentos de natureza repressiva, os elementos destacados pela Justiça Militar para compor o rastro de perseguições aos intelectuais entre outros setores sociais que ousaram desafiar a (s) Ditadura (s). O mapeamento completo, envolvendo as estratégias de combate ao "comunismo", englobando conhecimento dos partidos e dos seus quadros militantes, foi acumulado por órgãos policiais e militares ao longo do século XX. Buscamos acompanhar, através desses registros, a trajetória política do intelectual Jacob Gorender. Como jornalista, envolveu-se na discussão sobre a participação brasileira na II Guerra Mundial, ingressando em 1943 na FEB. Antes, porém, Gorender tornou-se comunista, recrutado por Mário Alves em 1942. Até meados dos anos sessenta, atuou como militante e dirigente do PCB, quando resolveu ingressar no PCBR, fundado em 1968. O historiador, nos momentos iniciais do Golpe de 1964, já com a vida devastada pela Comunidade de Informação e Segurança, experimentou a clandestinidade, prisão, tortura e censura aos seus escritos entre outros abusos que atingiram também os amigos mais próximos, companheiros de partido e familiares. $O$ cruzamento dessas informações com os textos memorialísticos ajudam a compreender as artimanhas da repressão política e os diferentes projetos de Revolução em curso.

Palavras-chave: Autoritarismo. Repressão. Jacob Gorender.

\section{ABSTRACT}

The purpose of the article is to demonstrate through analysis of documents of repressive nature, the elements highlighted by the Military Justice to establish the trace of persecution of the intellectuals among other social sectors which dared to challenge the Dictatorship. The complete mapping, involving the combat strategies against the "communism", including the knowledge of the political parties and

1 Doutora em História Social pela Universidade de São Paulo (2004). Mestre em História pela PUC/SP (1993). Graduada em História pela PUC/SP (1989). Atualmente, Professora Adjunta IV do Departamento e do Programa de Pós-graduação em História da Universidade Federal da Bahia. 
their military staff, was accumulated by police and military sectors along the 20th century. We intended to follow, through these records, the political trajectory of the intellectual Jacob Gorender. As a journalist, he got involved in the discussion about the Brazilian participation in the World War II, joined the FEB in 1943. Before that, however, Gorender became a communist, recruited by Mario Alves in 1942. In the early 60's, he acted as a militant and coordinator of PCB, when he decided to join PCBR, founded in 1968. The historian, in the beginning of the 1964 Strike, with his life already devastated by the Information and Security Community, experienced marginalization, imprisonment, torture and censorship of his writings among other abuses that also reached his closest friends, political companions and family members. The crossing of this amount of information with the memorial documents helps to understand the political repression tricks and the different Revolutionary projects in course.

Keyword: Authoritarianism. Repression. Jacob Gorender.

Inicialmente, recuperamos alguns traços biográficos do intelectual e militante comunista Jacob Gorender, compreendendo o enfrentamento com a (s) Ditadura (s) do Estado Novo, (1937-45) e a Civil-Militar (1964-1985). As participação na Segunda Guerra Mundial e a militância no Partido Comunista do Brasil são componentes chaves de sua biografia. Após a inflexão política de 1964, crises, dissidências, prisão, tortura, clandestinidade, cassação dos direitos políticos, conformaram uma experiência que repercute ainda hoje, para além de legitimar uma resistência que faz do historiador um dos ícones de parte da esquerda brasileira.

Jacob Gorender, 88 anos, nasceu em Salvador em 20 de janeiro de 1923, filho de imigrantes judeus de origem russa. Sofreu influências do pai, homem de esquerda, antisionista, que lutou ao lado dos operários na fracassada Revolução de 1905. Quando imigrou para o Brasil, seu pai defendeu com grande entusiasmo o ideário do movimento revolucionário russo de 1917. A inclinação para militância política teve início aos 19 anos na Faculdade de Direito em Salvador na década de trinta, como dirigente da União dos Estudantes da Bahia. Salvador foi o centro irradiador do comunismo, principalmente pelo afluxo de militantes politizados vindos de outros estados em decorrência do cerco repressivo estabelecido pelo governo Vargas após o Levante de 1935.

Para Gorender ser militante de esquerda nessa época, significou lutar contra o fascismo e defender Stálin: "minha cultura marxista se iniciou pela via da adesão ao stalinismo" (AZEVEDO; MAUÉS, 1997, p. 188). Participou da campanha expedicionária na Itália em 1944 no contexto da Segunda Guerra Mundial e, entre 1951 e 1953, integrou o secretariado do Comitê Estadual do PCB em São Paulo, liderado pelo ex-deputado federal, Carlos Marighella. Atuou como encarregado do setor de propaganda e ligações com o meio intelectual, embora buscasse contatos também com a base operária. Em abril de 1957, regressou ao Brasil, após quase dois anos na União Soviética, quando participou do $20^{\circ}$ Congresso do PCUS, realizado em Moscou. Assumiu a direção da Imprensa Popular, depois trocou a direção do jornal com Mário Alves, passando a dirigir a Voz Operária, órgão oficial do partido. 
Em 1967, Gorender foi expulso do PCB, juntamente com Mário Alves e Carlos Marighella, rompendo definitivamente com a tese da "coexistência pacífica", liderada por Luís Carlos Prestes. Mário Alves, Jacob Gorender e Apolônio de Carvalho fundaram em 1968 o PCBR, Partido Comunista Brasileiro Revolucionário, cuja linha de ação seguia o caminho da violência revolucionária a ser conduzida pelas classes sociais condicionadas por forças históricas favoráveis à revolução socialista. Carlos Marighella fundou a ALN, Aliança Nacional Libertadora, mantendo uma linha militarista de ação, empregando novas técnicas de guerrilha urbana, porém, defendendo o caminho da luta armada, próxima da "teoria do foco" cubana. As divergências entre o PCBR e a ALN resultaram dessas diferentes estratégias para a tomada do poder.

Com a deflagração do Golpe de Estado, Gorender foi indiciado no IPM do PCB, instaurado em 1964, ocorrendo à cassação dos seus direitos políticos por dez anos em 1966. Após seis anos vivendo a difícil experiência da clandestinidade, o historiador preso em 1970, foi torturado pela equipe do delegado Sérgio Paranhos Fleury. Sobreviveu à violência perpetrada pelo Estado de Segurança Nacional e tornou-se um dos presos políticos mais atuantes no Presídio Tiradentes em São Paulo. A prisão de Gorender não aconteceu isoladamente, entre outros presos políticos, destaca-se o penoso processo que atingiu a sua esposa, Idealina da Silva Fernandes, filha de Hermogênio da Silva. Fernandes, um dos primeiros dirigentes do Partido Comunista do Brasil.

Autodidata $^{2}$, militante de sólida formação intelectual, Gorender publicou diversos artigos e livros tendo como pressuposto o materialismo histórico e dialético ao analisar vários aspectos da história brasileira em momentos distintos. Apresenta uma produção historiográfica conhecida dentro e fora da comunidade acadêmica, principalmente pelos seus livros O Escravismo Colonial, 1978 e Combate nas Trevas, 1987. Em 1999, recebeu o troféu Juca Pato, prêmio de intelectual do ano, pela União Brasileira de Escritores. Além de historiador, atuou vários anos como jornalista e tradutor, escrevendo principalmente em órgãos de esquerda. Nos seus escritos sobre a Ditadura Civil-Militar, dedicou-se a analisar o comportamento das esquerdas, enfatizando as crises internas do PCB no período pré e pós64. Também foi professor visitante do Instituto de Estudos Avançados da Universidade de São Paulo e ministrou em 1997 um curso de pós-graduação sobre "História do Marxismo" no Departamento de História da USP.

O resumo de sua biografia justifica-se para estabelecermos o objetivo central dessa análise, consistindo em demonstrar que a perseguição e o enquadramento desse homem como "inimigo interno da nação" foi guiada por fortes convicções dos agentes repressivos

2 Jacob Gorender não conseguiu concluir o curso superior na Faculdade de Direito em Salvador nos anos trinta do século XX. Ver Memórias de Jacob Gorender - A Esquerda Revelada. Documentário, lançado em 8/10/2009 e realizado pela TV Câmara em parceria com a UnB, exibindo trechos da entrevista em que rememora a infância pobre na capital da Bahia, o início da militância, aos 19 anos de idade, além de tecer considerações sobre a história da esquerda brasileira, matizada por preocupações com o mundo atual. 
de que estavam lidando com um grande nome do comunismo internacional, um elemento que representava um perigo à estabilidade do capitalismo brasileiro, além de divulgador da teoria e ideologia marxista, especialmente nos meios universitários. ${ }^{3}$ Organizamos o percurso desse artigo através de três eixos investigativos: no primeiro, realizamos uma descrição e análise do corpus documental produzido pelos órgãos repressivos e, em parte, coletados pela Justiça Militar com destaque para aspectos de sua biografia política a partir dos anos quarenta até os anos sessenta do século passado; no segundo, aprofundamos o conhecimento dessa massa documental através do caso das Cadernetas Prestes, contrapondo a versão oficial à interpretação produzida pelo próprio Gorender e, por último, estudamos o mapeamento realizado pelos órgãos repressivos desde a formação do PCBR em 1968, ao momento de formulação, desenvolvimento e derrocada da luta armada. Aqui, buscamos sempre uma interlocução com os escritos do historiador que amplia, corrige e coloca novas questões sobre os fatos investigados nessa pesquisa.

Assim, para contrapor a versão apresentada pelos órgãos repressivos e esclarecer melhor os episódios envolvendo a vida de Jacob Gorender, realizamos um cruzamento dessas informações com os seus escritos memorialísticos, levando-se em conta os componentes (auto) biográficos. Estamos nos referindo ao conjunto de memória escrita, compreendendo depoimentos anexados aos processos, entrevistas publicadas em jornais, revistas e livros e um depoimento gravado para o documentário Memórias de Jacob Gorender - A Esquerda Revelada, 2009. A sua contribuição para a historiografia do período militar, especialmente com a publicação do livro Combate nas Trevas. A Esquerda Brasileira: das ilusões perdidas à luta armada, 1987, provoca uma leitura das esquerdas brasileira realizada por um dos seus sobreviventes. Com isso, buscou-se caracterizar as atitudes e posturas do historiador frente a sua condição de perseguido e preso político da ditadura.

3 Consultamos Documentos datados de 1947 a 1983, totalizando 141 pastas/Série Dossiês. Inicialmente, na intenção de recuperar a trajetória de Gorender e a vigilância a ele estabelecida pelo DEOPS/SP, consultamos as fichas nominais da série "Dossiês", que retratam investigações iniciais do órgão em relação a suas atividades militantes e acadêmicas. Através da consulta preliminar a estas fichas, chegamos às pastas-resumo do historiador, identificadas com o código alfanumérico 52-Z-0, que representa uma subsérie com diversos volumes ou pastas. As pastas-resumo remetem à identificação de documentos localizados em outras pastas. Esse resumo de referência foi fundamental para localizarmos todos os documentos existentes nas pastas da série "Dossiês", o que demonstra, ao mesmo tempo, o controle exercido pelo DEOPS/SP através de relatórios elaborados por agentes de informação. Com a extinção do DEOPS/SP em 1983, os agentes da Polícia Federal elaboraram resumos da Série Dossiês, 52-Z-0, pastas 549 a 583, atendendo a solicitações de outros órgãos de repressão. Jacob Gorender teve as suas atividades políticas resumidas em nove folhas arquivadas em pasta de referência 52-Z-0-9148, elaborado pela Secretaria da Segurança Pública/Dependência/Serviço de Informações/DOPS. Geralmente, os relatórios são confeccionados em papel timbrado, onde consta o carimbo Confidencial e disponibilizados para a Comunidade de Informações. 


\section{Polícia Política e Justiça Militar}

Normas de controle e vigilância são visíveis na documentação produzida pelo Departamento de Ordem Política e Social - DOPS, ao longo das décadas de quarenta a oitenta do século XX. ${ }^{4}$ Evidentemente, que as ações ganharam maior desenvoltura após o Golpe de 1964, encontrando na Justiça Militar o respaldo necessário para a sua atuação. Tornou-se imperativo entre os anos de 1968 a 1975 "descentralizar" a máquina repressora para combater às forças de resistência, especialmente a luta armada dirigida por organizações clandestinas distribuídas por pequenos núcleos em todo país. Assim, cada órgão policial e militar adquiriu uma autonomia de decisão e ação sem paralelo na história das instituições policiais brasileiras no século XX. Os documentos também revelam o pragmatismo e o espírito dos chefes do combate à "subversão", convictos do projeto de modernização conservadora, sintonizados que estavam com um mundo imerso na Guerra Fria.

O DOPS não foi uma exceção, e é aqui, exatamente no período governado por cinco generais presidentes, que se registra o maior conjunto documental da instituição. No entanto, esses documentos não podem ser considerados como fontes seguras para a construção da verdade histórica, mesmo considerando seu caráter múltiplo e transitório. Informações falsas, exageros, mentiras e lacunas particularizam os processos, reveladores dos crimes políticos cometidos pela Ditadura Civil-Militar. Os conteúdos são fortemente ideologizados e carregados de significados que ultrapassam a versão dos envolvidos, permitindo a crítica e uma leitura mais ampla de como militares e civis envolvidos com a prática da tortura agiam.

Os processos oriundos da Justiça Militar, arquivados pelo Projeto Brasil Nunca Mais e aqui analisados, reúnem uma série de documentos advindos de vários órgãos de repressão de diferentes Estados brasileiros. São prontuários, dossiês com dados de qualificação, antecedentes, cartas e informes, retratando a longa militância política de Jacob Gorender no PCB. ${ }^{5}$ Os documentos informam que durante o Estado Novo, 1937-45, seu empenho nas transformações sociais e sua postura teórica marxista já incomodavam a polícia política. $\mathrm{O}$ perfil do intelectual é alicerçado como uma das "mais brilhantes penas do Marxismo-

4 Em 1924, criou-se a "Delegacia de Ordem Política e Social" com a finalidade de manter sob controle as ações dos cidadãos em geral, principalmente pela emergência e consolidação da participação política de setores operários urbanos fortalecidos por largos contingentes de imigrantes. Em 1939, início da Segunda Guerra Mundial e intensificação das atividades do Partido Comunista Brasileiro (que se encontrava na ilegalidade), o DOPS voltou-se para repressão aos comunistas. Também merece destaque, neste mesmo ano, a aplicação das leis de economia popular e o aumento da vigilância com relação às greves. Até meados da década de 50, os principais alvos do DOPS foram os estrangeiros no país e os comunistas.

5 Pesquisamos o Tomo II, Vol. 2, dividido em: "Perfil das Organizações de Esquerda" (PCB, PC do B, MR-8, VPR, PCR, ALN entre outras), "Perfil dos Setores Sociais", envolvendo os processos de militares, sindicalistas, estudantes, políticos, jornalistas e religiosos, e "Perfil dos Atingidos", em que localizamos os processos do historiador organizados numa lista dos "denunciados" e dos "não denunciados". Jacob Gorender aparece na "Relação dos Atingidos" (denunciados) em 2 processos e na relação alfabética de indiciados ("não denunciados") como jornalista e tradutor em mais 2 processos. 
leninismo na América", especialista em política internacional e profundo conhecedor da realidade brasileira. Homem de origem israelita e dirigente da propaganda nacionalista do PCB. O Ministério da Guerra/I Exército relatou minuciosamente as atividades de Jacob Gorender, de 43 anos de idade, filho de Natan Gorender e Ana Gorender:

\begin{abstract}
Este indiciado foi um dos mais destacados membros do Comitê Central do Partido Comunista Brasileiro. Utilizou sua capacidade intelectual em benefício do movimento comunista no Brasil. Propagandista entusiasta da doutrina marxista-leninista procurou divulgá-la no Brasil inteiro. Com esse objetivo, promoveu conferências em vários Estados da Federação e foi colaborador intenso de vários jornais comunistas que circularam no Brasil nos últimos vinte anos. Por sua atividade, galgou rapidamente cargos de direção do PCB, foi considerado um dos principais teóricos do mesmo. ${ }^{6}$
\end{abstract}

Jacob Gorender foi preso pela primeira vez em 13/7/1943, por ordem do general Comandante da VI Região Militar sob acusação de publicar uma entrevista polêmica feita com o general Manoel Rabelo em defesa da participação do Brasil na Segunda Guerra Mundial, publicada na Revista "SEIVA", secretariada por ele. ${ }^{7}$ Permaneceu na prisão por 27 dias, à disposição do Tribunal de Segurança Nacional, depois liberado por determinação do Ministro da Guerra, em 10/8/1943. Em 1945, discursou em debate público sobre as rearticulações do Integralismo, evento organizado pela União dos Estudantes da Bahia e Associação dos Empregados do Comércio na Bahia. De acordo com as fontes processuais, Gorender declarou que o Integralismo fora criado como um partido todo fascista, feito à forma de Mussolini, Hitler e da falange Francesa. Para o historiador, os jornais brasileiros foram fascistas tanto quanto os integralistas, pois, publicavam cartas abertas, escritas por fascistas, "verdadeiros traidores do Brasil". ${ }^{8}$

Em 27 de novembro de 1947, o Jornal do Povo, publicou um artigo em que o "marginado" incitava o povo contra o Governo Dutra (1946-1950). O mesmo jornal publicou manifesto de intelectuais, cientistas e jornalistas sob o título: "Contra as manobras fascistas de retorno à ditadura", onde consta o nome de Jacob Gorender. ${ }^{9}$ Artigos, conferências, cursos são enumerados no relatório. Contudo, dá-se destaque ao artigo em que Gorender elogia a obra de Stálin, em especial como autor do compêndio de História do Partido Comunista da URSS,

6 Documento do Ministério da Guerra/I Exército, anexado no Relatório do PCB, elaborado pelo coronel Ferdinando de Carvalho, base do Inquérito Policial Militar, datado de 1964

7 A Revista Seiva foi de iniciativa do Comitê Regional do PCB baiano com o fito de driblar a censura e combater o fascismo no contexto da Ditadura Vargas. Foram 18 edições entre os anos de 1938 a 1943. Proibida de circular em julho de 1943 pelo Estado Novo. Jorge Amado, João Falcão, Gorender, entre outros, escreviam na revista. Nos anos cinquenta voltou a circular com novas características. Ver. Falcão (2008).

8 Informação retirada dos Processos n ${ }^{\circ} 279$ e n. ${ }^{\circ}$ 517, baseadas no relatório elaborado pelo DOPS/MG que registra os Antecedentes de Jacob Gorender. - Acervo BNM.

9 Jornal do Povo, 25/5/1947, p.8. O Manifesto também foi publicado simultaneamente no jornal O Correio da Manhã/RJ e em O Estado de São Paulo. 
editado em 1938, que rapidamente transformou-se na obra mais divulgada da literatura marxista: "Tornou-se familiar para o comunista chinês como para o russo ou o norteamericano. Através do seu texto vêm se educando não só os simples militares de fileiras como os dirigentes carregados de responsabilidades". ${ }^{10}$ No final, de acordo com o relatório, queixa-se de que muitos comunistas brasileiros não conheceram a obra de Stálin, em especial, sua crença de que é mais interessante fazer a História do que escrevê-la. Este registro aponta para a formação teórica e política do historiador, comprometida com o stalinismo. Destarte, através de entrevistas e publicações recentes, é possível identificar suas posições teóricas no campo do marxismo renovado e na crítica ao stalinismo.

Para completar e sistematizar as informações sobre o acusado, a Secretária de Segurança Pública elaborou um documento retratando Gorender como elemento "perigoso" desde os anos quarenta, com destaque para o seu elogio ao líder soviético, Stálin, e ao enaltecimento da figura de Prestes:

\begin{abstract}
Sem qualificação, que trabalhava no jornal A Classe Operária [...], militante comunista e mantinha correspondência com o comunista italiano Otávio Margotti. Foi delegado fundador da Associação dos Excombatentes, pelo Estado da Bahia. [...] Segundo anotações de 17.12.1947, o epigrafado era guarda-costas de Luiz Carlos Prestes. O jornal comunista "Classe Operária", de 1.1.49, publicou um artigo do epigrafado sob o título. "A solução revolucionária para o problema da terra". Era membro suplente do Comitê Estadual do PCB, da Bahia. A "Voz Operária" de 31.12.49 publicou um artigo intitulado "Prestes e o Movimento Nacional Libertador de 1935", de autoria do marginado, em comemoração ao $52^{\circ}$ aniversário de Prestes. Publicou outros artigos nos jornais comunistas, sempre enaltecendo as qualidades de seu líder Luiz Carlos Prestes. Segundo a "Imprensa Popular de 15.4.50, foi signatário de uma mensagem aos comunistas espanhóis, por ocasião da data de aniversário do PC espanhol. Segundo anotações feitas em 27.9.1951, é antigo militante comunista, tendo sido preso em 1943 por atividades subversivas. Segundo recorte da "Imprensa Popular" de 7.4.53, o marginado publicou um artigo intitulado "Tu nos destes a honra, a bandeira, o Partido", onde, referindo-se a Stálin, enaltece suas qualidades, seus feitos e comenta sua morte como perda. Comentou sobre os pracinhas brasileiros na guerra, irmanados com os pracinhas soviéticos, lutando pela bandeira da Rússia, etc. Em outubro de 1947 dirigiu telegrama ao Presidente da República, protestando contra a cassação do PCB. ${ }^{11}$
\end{abstract}

Ainda, segundo o Relatório de Informação Reservada, elaborado em 1959, Jacob Gorender publicou em 1951 um artigo, intitulado "Pequena Biografia de Luiz Carlos Prestes". Ocupou em 1952, o cargo de "Secretário de Agitação" na Direção Estadual do PC de São Paulo.

10 Jacob Gorender. Jornal "Voz Operária”, 17/12/1949.

11 BNM/Processo $n^{\circ}$ 279/cx.1-B e cx.2. s/d. 
Foi qualificado de "profundo erudito em Ciências Internacionais e em Política Internacional", falando e escrevendo em diversos idiomas. Durante os trabalhos do IV Congresso do PCB, novembro de 1954, Jacob Gorender, sob pseudônimo de "Sabino Bahia", redigiu e apresentou a tese, "Preparação, Formação e Educação dos Quadros do PCB", merecendo o aplauso do Comitê Central do Partido Comunista da URSS.

Jacob Gorender também foi indiciado no Processo $n^{\circ} 279$ contra o PCB. Este processo foi baseado no rumoroso e caótico IPM do Coronel Ferdinando de Carvalho de 1964, no Rio de Janeiro, que chegou a indiciar até mesmo o ex-presidente Juscelino Kubitschek como suposto elemento simpatizante do partido. Os principais alvos da repressão política foram os setores ligados ao Governo Goulart e à campanha pelas Reformas de Base, concentrados, principalmente, nos sindicatos urbanos e rurais, em setores das Forças Armadas e, ainda, nos chamados "Grupo dos Onze" ou "Comandos Nacionalistas".

O coronel Ferdinando Carvalho, analisa as atividades dele como dirigente do PCB e membro do Comitê Central desde 1954, quando participou do IV Congresso do Partido, realizado em São Paulo. Vários documentos comprometem Gorender com a cúpula do PCB, destacando-se a Ata da reunião do Comitê Central em 1963, manuscrito apreendido no escritório de Luiz Carlos Prestes que designa Gorender para fazer parte da Comissão Executiva do projeto de Teses para Discussão. $\mathrm{O}$ coronel informa que Gorender pertenceu à cúpula do Partido, tornou-se "elemento assíduo" de reuniões partidárias, e com isso, citado inúmeras vezes nas Cadernetas de Prestes. Assevera também que Gorender foi intimado a depor pelo Diário Oficial de 28 de setembro de 1965, mas não cumpriu a determinação.

Cabe destacar que procedemos à investigação de temas referenciais dos Inquéritos Policiais Militares, IPMS, envolvendo Jacob Gorender e instaurados no primeiro governo militar sob o comando do general Castelo Branco, 1964-672. Tais fontes oferecem ricos detalhes sobre a perseguição e as diferentes estratégias de resistência que culminaram com a absolvição do acusado. Os argumentos oferecidos pelo próprio Gorender e pela Defensoria Pública confirmam o aporte jurídico do enquadramento indevido de Gorender na Lei de Segurança Nacional, LSN:

CONSIDERANDO que o indiciado JACOB GORENDER, tomou parte em reuniões realizadas pelo indiciado Luiz Carlos Prestes, e era membro dirigente do PCB.

CONSIDERANDO que em reunião do Partido, quando se debatia as novas linhas a seguir, isto é, aquelas ditadas pelos camaradas soviéticos, tomou a palavra, analisou e discutiu assuntos, demonstrando ser um profundo conhecedor dos mesmos, e o é pois

12 Os IPMs foram típicos de 1964, muitas vezes intitulado IPM do Partido Comunista, apurava atividades mistas (sindical, estudantil, militar, etc.), com caráter de 'devassa' regional'. Projeto BNM/Tomo II, vol.1, 1985, p.11. 
vários contactos internacionais realizou, com o fito de obter o pensamento, a linha a seguir pelos partidos comunistas.

CONSIDERANDO que pondo em prática os ensinamentos recebidos dos camaradas soviéticos, declarou em reunião do Partido 'Legalidade constitucional. [...] Quem pode dar o golpe agora é o Jango. ${ }^{13}$

Jacob Gorender, Carlos Marighella e Hércules Corrêa dos Reis foram acusados e incriminados pela LSN. As razões são fundamentadas no fato de que Gorender, como membro dirigente do $\mathrm{PCB}$, recebia orientação das potências estrangeiras, Rússia, e defendia o socialismo cubano. Os argumentos que levaram a criminalização de Gorender são meramente ideológicos, contradizendo a própria LSN, que previa apenas punições para os que praticavam ações armadas.

Com a prisão de Jacob Gorender, "veio à luz toda a trama que visava àquela reorganização, tendo sido apreendido em poder do mesmo farto material de natureza anarco-comunista e altamente subversivo". ${ }^{14}$ Condenado pela Justiça a cinco anos de reclusão, Gorender não cumpriu a pena. Carimbado como elemento "Foragido", utilizou documentos falsos, apesar do seu enquadramento em uma nova Lei de Segurança Nacional que passou a vigorar no Brasil em setembro de 1969, o Decreto-Lei no. 898, trazendo profundas alterações no tocante à definição dos crimes e intensidade das penas, prevendo, inclusive pena de morte e de prisão perpétua. Também dava pleno arbítrio aos juízes dos tribunais militares que, "para além das provas contidas nos processos, poderiam inspirar-se nos conceitos básicos da segurança nacional para decidir sobre a culpabilidade dos acusados" ${ }^{15}$. Este Decreto só foi substituído em 17 de dezembro de 1978 com a promulgação da Lei no. 6620, que abrandava as penas anteriormente capituladas e suprimia as de morte e prisão perpétua.

\section{O caso das Cadernetas Prestes}

As Cadernetas Prestes apreendidas em São Paulo em 9/04/1964, veio confirmar a abundante informação sobre a estrutura e o desenvolvimento das atividades no interior do PCB. A casa do líder comunista Luís Carlos Prestes foi invadida por policiais que procederam

13 "É expressiva a manifestação do denunciado, Jacob Gorender, em uma reunião - "Discussão Política" - defendendo um golpe comunista com a liderança de Jango e incitando os camponeses na luta pela terra". (Cad. 14, p. 161 e 177). Resumo do Inquérito instaurado contra o PCB, DOPS, 1964, p.29.

14 Informação retirada do Relatório dos Indiciados elaborado pelo DOPS/SP, em nove de março de 1970.

15Na verdade, a LSN foi criada em 1967. Em março de 1969, o Decreto-Lei 414 sofreria alteração através de outro Decretolei, o de $\mathrm{n}^{\circ} 510$, em cujo texto destaca-se uma nova modalidade de prisão em que o indiciado poderia ser mantido em estado de incomunicabilidade por um prazo de até dez dias, desde que essa medida fosse necessária às averiguações policiais (art. 47, Parágrafo $1^{\circ}$ ). Antes do advento do Decreto-Lei 510/69, o AI-5, de 13 de dezembro de 1968, incumbiu-se de suspender a garantia de Habeas corpus nos casos de crimes políticos contra a Segurança Nacional, a ordem econômica e social e a economia popular. Informações retiradas do BNM - Tomo IV, 1985:7. 
a busca das Cadernetas. Trata-se de várias espirais com anotações de Prestes sobre as reuniões, detalhando os nomes de participantes, assuntos discutidos, locais, entre outras informações, algo semelhante a um Livro de Atas com a vida do Partido nos últimos anos.

O DOPS elaborou em 30/09/1964 um resumo do inquérito instaurado contra Luiz Carlos Prestes, incluindo a investigação sobre Gorender e vários outros militantes. ${ }^{16}$ Dezenove (19) cadernetas, tipo espiral, encontradas na residência do indiciado Luiz Carlos Prestes foram anexadas ao processo:

Julgadas, entre todas as apreensões efetuadas, as mais importantes, eis que é uma documentação que contêm, de forma resumida, toda a atividade do Partido Comunista Brasileiro destes últimos 3 anos e algumas centenas de nomes, não só de alta projeção no cenário comunista nacional, como de elementos políticos brasileiros que, de uma forma ou de outra, mantinham certas ligações com os comunistas do Brasil, além de conter relatórios e informações, as mais variadas, sobre as viagens que eram realizadas pelos comunistas brasileiros ao estrangeiro, em ligação com os comunistas dos países percorridos. ${ }^{17}$

Entre as referências transcritas, destacamos as anotações das Cadernetas $n^{\circ} 13$ e $n^{\circ} 14$, onde se lêem respectivamente os seguintes trechos comprometedores da materialidade de sua militância comunista:

Mensagem ao Congresso do PC Uruguaio. Jacob viajará 4 ' feira. "Jacob (delegado fraternal ao Congresso do PC Uruguaio", o que demonstra ter sido o indiciado, representante do PCB, em Montevidéu no Congresso de PC do Uruguai em 1962" (Caderneta n. $^{\circ}$ 13, p.42).

Não é fácil para mim intervir mas quero dar uma opinião - legalidade constitucional - palavra de ordem que devemos retirar rigorosamente

16 O inquérito foi iniciado no dia 7 de abril de 1964 e encerrado em 30 de setembro de 1964, com duração de 5 meses e 23 dias. Foram compilados 10 volumes, num total de 2.099 folhas. O relatório final se compõe de 403 folhas datilografadas. Também foi anexado aos autos um volume em separado, que passou a denominar-se "Anexo", contendo 287 folhas, todas referentes a documentos encontrados na residência de Luiz Carlos Prestes. Essas cadernetas somam 3.426 páginas, todas manuscritas a tinta e de punho do indiciado, Luiz Carlos Prestes. Foram indiciados no inquérito setenta e quatro pessoas. De todos os indiciados foi possível qualificar diretamente dezoito (18). Sobre os restantes, em número de 56, "todos foragidos ou em lugares incertos e não sabidos, foi possível obter-se elementos, ou dados, que nos permitiram qualificálos de certa forma". Compilou-se um índice do inquérito, contendo todos os nomes dos indiciados, obedecendo a rigorosa ordem alfabética. E, finalmente, dentro do corpo do próprio ÍNDICE, nas respectivas letras, colocou-se o significado das siglas e abreviaturas das organizações, partidos, nomes, etc., que são citados no RELATÓRIO final do inquérito Proc. $n^{\circ}$ 255/cx.7. Acervo BNM.

17Jacob Gorender é citado nas Cadernetas de Prestes n. ${ }^{\circ}$ 1, 2, 4, 5, 6, 8, 13, 14, 16 e 19 como um profundo conhecedor dos assuntos abordados pelos comunistas, isto é, latifúndio, frente única, erros do Partido, etc. (Cad. 2. p.63; Cad. 4. P. 19).Também encontramos referências de pessoas indiciadas junto com Gorender que estão nomeadas nas Cadernetas: Mário Alves, Apolônio de Carvalho e Renato para a Seção de Educação do PCB (Cad. 6, p. 140). Mais informações foram retiradas das anotações de Prestes: Gorender apresentou sugestões quando da preparação do VI Congresso do PCB (Cad. 3 , p. 8). Resumo do Inquérito instaurado contra o PCB, elaborado pelo DEOSP/SP em 30/09/1964. Processo. n ${ }^{\circ} 255 / \mathrm{cx}^{2}$. Acervo BNM. 
agora. Quem pode dar o golpe agora é o Jango. Legalidade é o Parlamento, que é profundamente reacionário. 'Ampliar a Luta'. Levar os camponeses a lutar pela terra. Dar uma forma organizada à tomada de víveres, etc. (Caderneta ${ }^{\circ}$ 14, p.156).

Ao analisar a declaração de Gorender, o coronel Ferdinando discute a inevitabilidade do emprego da violência por parte dos comunistas: "Essa sua intervenção é surpreendente pela simplicidade com que encara a ação violenta. Cremos que estamos diante de um comunista de grande capacidade de inteligência, convicção ideológica e de ação."18 Aqui, notamos um certo incômodo dos homens da repressão em lidar com intelectuais, mesmo os considerados de "esprírito comunista violento".

Apelações importantes, anexadas ao Processo n. ${ }^{\circ}$ 255, 1966, evidenciam os trâmites dos advogados de defesa para tentar atenuar a pena de cinco anos de reclusão imposta pelo Tribunal Superior Militar a Jacob Gorender em decorrência das Cadernetas de Prestes.

Do inquérito instaurado resultou uma ação penal onde figurou cerca de 72 denunciados, muitos deles condenados a penas elevadas. Pois bem, não há ao longo do processo uma perícia para atestar se as Cadernetas foram realmente escritas por Prestes. Apesar disso, essas cadernetas serviram para embasar sentença condenatória. ${ }^{19}$

A defesa pautou seus argumentos no fato de que o indivíduo por ser portador de ideais opostas ao regime capitalista, sistema dominante no mundo ocidental, não poderia ser punido e enquadrado na LSN. Gorender não cometeu nenhuma ação criminosa que justificasse sua condenação: "O próprio Papa João XXIII e Paulo VI são contrários ao regime capitalista, como Jesus Cristo o foi, até radicalmente". ${ }^{20} \mathrm{Um}$ dos advogados de defesa referindo-se aos acusados assegurou que o fato de terem os nomes citados nas Cadernetas, não "credencia nenhum crime, mesmo porque, são informações de terceiros, além do mais, se assim fosse, agiam politicamente, sem violência ou desrespeito às Leis do país". ${ }^{21}$ Em três de Maio de 1966, o Promotor Durval Moura de Araújo apresentou as razões finais que levou à condenação dos réus. Vale lembrar, que nesse período, 1966, Gorender esteve "foragido", mantendo-se na clandestinidade em São Paulo. Já em 1970, encontramos negociações dos seus advogados na tentativa de atenuar a pena de cinco anos de reclusão a que foi condenado em 1966, para 18 meses:

$20 \mathrm{Em} \mathrm{10/5/1966} \mathrm{o} \mathrm{advogado} \mathrm{de} \mathrm{Ofício} \mathrm{Juarez} \mathrm{A.} \mathrm{de} \mathrm{Alencar} \mathrm{encaminhou} \mathrm{uma} \mathrm{apelação} \mathrm{de} \mathrm{caráter} \mathrm{geral} \mathrm{na} \mathrm{tentativa} \mathrm{de}$ absolvição dos envolvidos no processo das Cadernetas.

21 Os argumentos básicos do advogado Raimundo Pascoal Barbosa em 18/3/1970 centra-se na questão da autenticidade das cadernetas. Processo no. 255. Acervo BNM. 
A polícia se baseou em conclusões de peritos dos seus próprios quadros, que são suspeitos, e em testemunhos de réus, que são leigos em matéria grafológica e não podiam, portanto, manifestar mais do que uma simples impressão pessoal, certamente influenciada pelas circunstâncias coatoras do interrogatório, além disso, seria preciso provar a autenticidade das Cadernetas, linha por linha, palavra por palavra, para que a prova das cadernetas pudesse ter validez relativa, nunca absoluta, no caso de cada réu. Isto não foi feito, o que suprime, mesmo, a referida validez relativa.

Não é possível, por outro lado, acreditar-se que o senhor Luiz Carlos Prestes fôsse tão ingênuo, anotando tudo o que era feito por ele e por seus companheiros, como se fosse um guarda-livros, deixando elementos que justificaram o envolvimento em processo e a condenação de dezenas de pessoas. (...) Se as CADERNETAS forem, de fato, escritas pelo antigo líder comunista, poder-se-ía afirmar, com segurança, que o mesmo estaria trabalhando para a polícia ou, então, estaria com a saúde mental abalada. ${ }^{22}$ (Grifo nosso)

O caso das Cadernetas Prestes só foi esclarecido quando o jornalista Lúcio Asfora, ao comentar o livro de memórias de Prestes, afirmou que "Prestes penitencia-se claramente da imprudência que levou à apreensão de suas anotações pessoais pela polícia e daí, à identificação e detenção de dezenas de líderes comunistas". ${ }^{23}$ Além das Cadernetas, Prestes guardou em seu poder, resumos completos de reuniões do Comitê Central.

Mais adiante o advogado relatou a trajetória intelectual de Jacob Gorender, reiterando que ninguém pode ser preso por manifestar liberdade de manifestação de pensamento. Ele nunca escondeu a sua condição de marxista, abordando temas de Filosofia, Sociologia, História e Economia do Brasil: "Fosse o recorrente, como se afirma neste lastimável processo, um conspirador, um agente da subversão, por certo, teria sido preso e processado em quase todos os estados do Brasil, onde foram lidos e ouvidos os trabalhos intelectuais do recorrente". ${ }^{24}$ Continua afirmando que não tiveram qualquer significação as anotações de Prestes, pois seria preciso provar que o JACÓ referido nas Cadernetas é, sempre, Jacob Gorender. Ainda, argumenta que como ter por certo que Prestes não se enganou a respeito de pessoas e de opiniões emitidas por estas, dado o grande número de reuniões e de participantes. Conclui que as referências a Jacó nas Cadernetas só informavam que o mesmo emitiu opiniões em reuniões, nada dizendo sobre os seus atos:

Na realidade, nega o recorrente, terminantemente, ter emitido tais opiniões. O recorrente, [...], só assume responsabilidade pelo que

\footnotetext{
22 Processo no. 255, cx.7 - Acervo BNM.

23 Matéria publicada no Jornal O Estado de São Paulo de 30/12/1981, intitulada "Prestes, a crítica e a autocrítica", Pasta 50K-118-795. Fundo DEOPS/São Paulo. Ver D. Moraes e F. Viana, Prestes: lutas e autocríticas. Petrópolis, Vozes, 1982. 24 Processo no. 255, cx.7 - Acervo BNM.
} 
assinou, pelos discursos e conferências que pronunciou, sempre, publicamente, como já afirmou. $O$ recorrente nada fez, clandestinamente. Não reconhece o recorrente em Prestes suficiente idoneidade intelectual para fazer anotações corretas de pronunciamento seus, se admitido, para efeito de raciocínio, que as Cadernetas sejam, mesmo, palavra por palavra, da autoria daquele cidadão. ${ }^{25}$

Para o advogado que redigiu a Apelação, o recorrente não participou de ações consideradas "subversivas". Integrou como voluntário a Força Expedicionária Brasileira durante a II Guerra Mundial para o "Teatro de Operações da Itália". Atuou como adepto do marxismo apenas no campo teórico, conformando o seu perfil de intelectual. Durante o período que residiu em São Paulo, não exerceu qualquer atividade violenta de ordem política que justificasse o seu enquadramento na LSN. Em Apelação datada de 17/08/1970, o advogado anexa aos autos, o depoimento escrito pelo próprio Gorender em que declara a sua condição de marxista e denuncia as violências praticadas contra a sua pessoa e a sua esposa Idealina Fernandes da Silva, como flagrante violação ao ordenamento jurídico e a própria Constituição vigente. Assim, redigiu o manuscrito, intitulado Subsídios para as Razões Finais, elaborando argumentos em que o próprio réu apontava aos juízes os caminhos para sua absolvição.

Declarei no meu depoimento na Polícia e o reiterei de viva voz, perante o Conselho de Justiça, na Auditoria, que fui e continuo sendo marxista. Estou disposto a sofrer qualquer penalidade por este motivo, se porventura existe alguma lei no Brasil que considere possível o fato de alguém ser marxista, isto é, de ser adepto confesso das idéias marxistas. Se nenhuma lei existe que estabeleça penalidade para a condição ideológica de marxista, então, qual o feito realmente delituoso que me pode ser atribuído?

Confirmei na Auditoria o Depoimento que prestei na Polícia, embora, conforme denunciei, este depoimento, se seguisse às mais terriveis torturas que foram infligidas, e se fizesse nesse ambiente de terror policial (grifo nosso). Ao confirmar meu depoimento na Auditoria atitude de pouquíssimos réus nos dias atuais -, não quis senão deixar [...] claro que não pretendo usar de subterfúgios perante a Justiça, mas, muito pelo contrário, assumir a plena responsabilidade pelos meus atos e pelas minhas idéias. Nada tenho do que me envergonhar neste depoimento, quer no referente à minha pessoa, quer no referente a outras pessoas, cujos nomes vieram à baila no interrogatório policial, nenhuma delas vítima de delação da minha parte. ${ }^{26}$

"Subsídios para as Razões Finais" foi citado por Gorender anos depois no livro Combate nas Trevas, 1987. O texto teve o propósito de confundir a Justiça Militar, assumindo o delito 
de fundação do PCBR durante vigência da Lei de Segurança Nacional, criada em 1967. A Lei prescrevia a pena de dois anos de reclusão para membros dirigentes de organizações da esquerda armada e demais contestadores do regime. Finaliza o documento, atento para o erro de ser julgado novamente pela LSN, atualizada em 1969, pois, a pena correspondente subiu de dois para cinco anos de reclusão:

\begin{abstract}
Minha argumentação atingiu o objetivo, o que se pode constatar pela sentença condenatória. $O$ Tribunal se viu diante de algo sem dúvida insólito: um réu confesso que apontava o dispositivo legal aplicável ao seu caso. Apegou-se à minha argumentação e me condenou a dois anos de reclusão. Na Apelação ao STM, o advogado George Tavares conseguiu anular a sentença de cinco anos de prisão, decorrente do PCBR para um ano (pena mínima, porque retornei à condição de réu primário). Libertado, vivi a situação de exílio no meu próprio País. Por muito amá-lo, não o deixei. (GORENDER, 1987, p. 224).
\end{abstract}

A Lei de Segurança Nacional punia a prática de ações violentas e não o pensamento, entendido como "a pregação sadia de idéias nobres". Com isso, os advogados firmaram o argumento da Defesa, cujo princípio foi de que assumir a condição de marxista não podia ser considerado crime. Respondendo a tal Apelação, o Promotor Durval A Moura de Araújo manteve a sentença de 5 anos de reclusão, argumentando que o próprio apelante se encontrava naquele momento, envolvido com outro processo em trânsito na Justiça Militar. Contrariando tal decisão, a Procuradora Marly Valle Monteiro no Rio de janeiro em 10/12/1970, aprovou a substituição da pena, condenando o acusado a 18 meses de detenção. ${ }^{27}$

O rumoroso Processo das Cadernetas Prestes foi analisado no livro Combate nas Trevas. Gorender não mede palavras para criticar e condenar a imprudente mania de Prestes em arquivar tudo que dizia respeito à sua personalidade. Prestes inicialmente pôs a culpa no anônimo ferroviário responsável por fazer a "limpeza" da casa, isentando-se da responsabilidade pelos seus atos. A notícia do ocorrido trouxe um dano moral devastador ao partido, levando militantes e intelectuais a responderem humilhantes interrogatórios até 1966. Alguns foram indiciados e condenados a 10 anos de prisão, e mesmo quando o Supremo Tribunal Federal, ao julgar recurso de um dos réus, resolveu que as Cadernetas não serviriam de prova condenatória, o estrago feito já não tinha volta. Muitos condenados na primeira instância sofreram prisões e alguns, já sentenciados, cumpriram pena integral.

\footnotetext{
27 Em 7 de Junho de 1971, o Supremo Tribunal Militar, tendo como Relator o Min. Dr. Waldemar Torres da Costa e como Revisor o Ministro Gen. Ex. Adalberto Pereira dos Santos, aprecia a Apelação de Jacob Gorender para fins de absolvição. $O$ STM afirma que a Procuradoria Geral reformou sua condenação a cinco anos de reclusão, pelos artigos $7^{\circ}$ e $9^{\circ}$ da Lei 1802/53, para fixá-la em dezoito meses de reclusão por infração ao artigo 36 do Decreto-Lei 314/67. Portanto, o STM impõe sua condenação a de 18 meses de reclusão, tendo-se em conta seus antecedentes políticos e a intensidade de sua atuação criminosa.
} 
Diante dos fatos, Gorender realiza um julgamento moral e passional da trajetória de Luís Carlos Prestes, construindo uma versão de teor mais memorialístico do que historiográfico.

Em 1997, Gorender responde às críticas feitas ao livro Combate nas Trevas com relação aos quarenta anos da trajetória de Prestes no PCB. Os críticos afirmam que perdera o distanciamento do historiador e se deixara levar por uma "certa personalidade" (AZEVEDO; MAUÉS, 1997, p.194). O historiador considera essas observações, mas não se curva, justificando: "se a dose parece excessiva, ela tem sua razão de ser". Sobre Prestes, comenta:

[...] é que ele vinha, naquela época, dando sucessivas entrevistas em que recompunha a sua biografia e a sua imagem histórica, culminando numa entrevista longa, que se transformou em livro, Lutas e Autocríticas. Aí ele se refere a numerosos fatos de sua longa trajetória, com distorções e falsificações. Eu, como historiador, não podia silenciar. Então, é por isso que a dose parece excessiva. É preciso considerar quem foi Prestes, o poder que ele teve durante decênios nos meios de esquerda, o mito que foi e ainda é. Eu não devia, nem queria, perder a oportunidade do livro que estava escrevendo para desmontar, na medida das minhas forças, esse mito de tantas conseqüências negativas para os comunistas e, em geral, para o movimento operário brasileiro (AZEVEDO; MAUÉS, 1997, p.194).

Observamos que a admiração profunda por Luís Carlos Prestes até meados dos anos cinquenta cede lugar às duras críticas nos anos posteriores. No entanto, o julgamento radical de Gorender com relação ao antigo líder comunista deve ser atenuado, especialmente, quando verificamos também contradições durante o seu percurso militante. No confronto com a máquina repressiva, Gorender aprisionado, descuidou-se da segurança de documentos importantes relacionados à vida partidária. O delegado Sérgio Fernando Paranhos Fleury, comandou em 21/1/1970, diligência em sua residência, localizada no bairro de Tucuruvi, em São Paulo, a fim de constatar a existência de documentos relacionados à "subversão". Foram enumerados no Auto de Busca e Apreensão, 28 documentos comprometedores das atividades de Gorender e sua esposa Idealina Silva Fernandes.

Essa ação policial com base nos documentos apreendidos resultou em novos interrogatórios, prisões, torturas de pessoas e familiares diretamente envolvidas com a luta política, bem como daqueles que nada sabiam. O casal de fiadores que auxiliou no aluguel do apartamento no bairro do Tucuruvi, foi interrogado, negando qualquer envolvimento com as atividades do inquilino. $\mathrm{O}$ acusado Jacob Gorender declarou inocência ao casal de fiadores responsável pelo aluguel do seu apartamento em São Paulo. ${ }^{28}$ Esse episódio assegura que a aplicabilidade de métodos de intimidação e tortura não atingiu somente os militantes mais

28 Auto de Qualificação e de Interrogatório, realizado no DEOPS/SP em 26/02/1970. 
diretos, mas, sobretudo, pessoas não familiarizadas com a política, os denominados pelos agentes da repressão de "inocentes úteis".

No apreço a verdade, é preciso dizer que Jacob Gorender despreza no caso das Cadernetas Prestes, a perspectiva de um relato "insento", "omisso", pautado apenas na factualidade, reafirmando o seu compromisso político. Entretanto, ao tratar de forma unilateral e com forte carga passional a história de Prestes, destaca-se como um de seus maiores contendores no campo da disputa de memórias opostas sobre o passado ditatorial. O seu Combate nas Trevas apresenta, nesse particular, todo o vigor de um texto com certo coeficiente memorialístico, permitindo amplos debates e provocando ainda hoje, polêmicas no meio da esquerda brasileira.

\section{Da formação do PCBR a autocrítica da Luta Armada}

No pré-1964, o DOPS paulista mantinha-se informado das atividades de Gorender, principalmente sua tentativa de reestruturar a União da Juventude Comunista, tendo seu irmão, Simão Gorender, como uma das grandes figuras ligadas ao movimento estudantil. Avaliavam que, no plano internacional, especialmente na América Latina, o movimento comunista, formado por estudantes e operários, estava organizado, penetrando em todos os setores na luta contra o imperialismo. Segundos os informantes do órgão, Mário Alves, Jover Telles e Gorender reagiram contra a política capitulacionista e reformista de Prestes em apoio a João Goulart. Inicialmente, a ala Prestes apoiou o seu governo, constituído, em sua maioria, por elementos conservadores e "serviçais do imperialismo, inclusive o ministro San Thiago Dantas, pseudo esquerdista e nacionalista, apoiado pelo governo norte-americano e pelo embaixador Lincoln Gordon" ${ }^{29}$ Posteriormente, com a grave crise inflacionária, Prestes convocou a CGT, Comando Geral dos Trabalhadores, responsabilizando o governo Goulart pela carestia de vida. "Estavam criadas as condições pré-revolucionárias que permitiram o golpe de estado em $64 "{ }^{30}$

Conferências, debates, artigos de jornais são alvo de comentários dos informantes do DOPS. Em 13/10/64, foi expedido Mandato de Prisão contra Jacob Gorender, pelo Dr. José Tinoco Barreto, Juiz Auditor da $2^{a}$ Auditoria da $2^{a}$ Região Militar, estando o epigrafado envolvido no processo referente às Cadernetas apreendidas na residência do líder comunista Luiz Carlos Prestes. No ano seguinte, o jornal "Folha da Manhã", de 20/06/65, informou que, com a prisão preventiva decretada, Jacob Gorender estava "foragido". Também através do jornal O Estado de São Paulo, 21 de maio de 1966, o DOPS tomou

29 O informante do DEOPS/SP, em 2/9/1963, destaca trechos referentes a Jacob Gorender, citados na palestra proferida pelo Prof. Calil Chader, líder do PC do Brasil, ala contrária a Luiz Carlos Prestes.

30 DAESP/Fundo DEOPS/Série Dossiês. Pasta 30-C-1-15406. 
conhecimento do decreto do general Castelo Branco suspendendo por 10 anos os direitos políticos de 59 dirigentes do PCB, constando nesta relação Jacob Gorender, condenado em 06/06/1966 a 5 anos como incurso nos artigos 9 e 7 da Lei 1802/53, pela $2^{\text {a }}$ Auditoria da $2^{a}$ Região Militar. Em 21/01/1970 foi preso na casa do médico Ayton Miranda Sipahi e levado para o Presídio Tiradentes, considerando-se que pertencia ao Comitê Nacional do PCBR, fato citado em várias declarações de presos políticos no DOI/CODI/IIEx. Permaneceu um ano e meio no Recolhimento de Presos Tiradentes sob a acusação "de prática de subversão e DA PREPARAÇÃO EM GRANDE ESCALA DE ATOS DE GUERRA REVOLUCIONÁRIA PARA A CONQUISTA DO PODER". ${ }^{31}$

Os processos n..$^{\circ} 11$ e n. 517 apresentam documentos que retratam a história do PCBR. Trata-se de versão construída pela polícia política que apostou no estudo sistemático das ações, definindo estratégias de eliminação dos seus núcleos militantes. O partido foi gerado entre as cisões ocorridas no PCB após 1964 como resultados do debate que se seguiu à definição de rumos para a luta revolucionária. A constituição formal do PCBR deu-se em abril de 1968 numa Conferência realizada do estado do Rio, onde a "Resolução Política" aprovada reunia as propostas fundamentais da nova organização. Contudo, os chefes da repressão informam que a origem do PCBR remonta a 1964, quando seu principal dirigente, Mário Alves, jornalista e intelectual de forte prestígio na Executiva do PCB, apresentou um plano de balanço dos acontecimentos que desembocaram no golpe militar, com uma visão oposta aquela utilizada pelos que se agruparam em torno de Prestes no Comitê Central. Também afirmam que sob a liderança de Mário Alves e Jacob Gorender reuniram- se cinco mil militantes e as mesmas linhas gerais inspiravam os fundadores da ALN, MR-8 e outras Dissidências. Ainda, segundo essa versão, Mário Alves aglutinou forças com o legendário dirigente comunista Apolônio de Carvalho, ex-combatente da Guerra Civil Espanhola, 193638, e herói da Resistência Francesa. Conseguiu adesão de Jacob Gorender, principal economista da direção do PCB, e Jover Telles, ex-deputado estadual no Rio de Janeiro, ligado ao movimento operário. O motivo que sustentou a denúncia contra Gorender, resultou na tentativa de reorganização do PCBR em 1969, prevendo a formação de um governo popular de esquerda:

Confessa, igualmente, que a partir de 31 de março de 1964 passou a viver em "aparelhos" do PCB, transferindo-se para São Paulo em 1965, e em 1967 alugou um apartamento à rua Iperoig, 871, sob o nome de Walter Arnold Weber [...] No Rio de Janeiro, quando ali residia, passou a usar o nome de Geraldo Heller Fernandes, para o que também usou de uma certidão de nascimento falsa. Justifica sua vinda a São Paulo por isso que aqui era menos conhecido que no Rio de Janeiro e aqui manteve contato com Joaquim Câmara Ferreira, vulgo "Toledo". Confessa o

31 Relatório "secreto" anexado ao IMP 709, elaborado pelo DOPS/RGS "S-2" em 1965, conforme notícia do Jornal ZERO HORA, em sua edição de 19/10/1964. Gorender foi posto em liberdade em 28/9/1971 através de Alvará de Soltura expedido pela $2^{\text {aa }}$ Auditoria do Regimento Militar. DAESP/Fundo DEOPS/Série Dossiês. Pasta 30-Z-160-11329. 
denunciado que era favorável à criação de um novo Partido, que preenchesse as funções não cumpridas pelo PCB, que fosse capaz de se vincular às massas trabalhadoras da cidade e do campo, no que discordavam Carlos Marighella e Joaquim Câmara Ferreira, favoráveis ao desencadeamento especialmente das guerrilhas urbanas e rural. Confessa que em abril de 1968 manteve contato no Rio de Janeiro com Mario Alves, no local da Tijuca, onde, juntamente com Apolônio de Carvalho, Miguel Batista, Armando Flutuoso, Jover Teles e outros elementos conhecidos do denunciado (cerca de 18 pessoas), e ali estabeleceram a base do PCBR, discutidos e aprovados os estatutos, havendo sido o nome do denunciado indicado para a composição do Comitê Central, havendo durado essa reunião cerca de 2 dias, após o que retornou a São Paulo. Após isso, compareceu a uma outra reunião do PCBR no Rio de Janeiro, onde se encontravam os mesmos conhecidos do denunciado. Embora condenasse o denunciado os terroristas, não pode abjurar da violência, pois "a considera como ação de massas dentro de determinadas condições objetivas, e não como ação arbritária, voluntarista e às vezes até mesmo irresponsável de pequenos grupos que não levam em conta para nada o estado de espírito e o grau de consciência política das massas, nem as condições concretas existentes". [...] Confessa que continua a se considerar como membro do PCBR, porém como elemento inativo. [...] Reconhece como tendo sido apreendidos em sua residência os documentos: "Teses Revolucionárias" [...], "Notas sobre alguns problemas da Revolução Guatemalteca"[...] Que é de sua autoria o documento "Caráter e Caminhos da Revolução Brasileira" [...] Que o denunciado confessa que em seus contatos em São Paulo ora usava o pseudônimo de "Sabino" ou "Cláudio. ${ }^{32}$

Em várias declarações de pessoas interrogadas pelo DEOPS/SP, Jacob Gorender é citado como membro do PCBR. Alguns colocam Gorender, após expulsão do PCB em 1967, como defensor da linha da ALN de Carlos Marighella. Os próprios órgãos de segurança associam o PCBR, liderado por Jacob Gorender, com a linha política da ALN de Carlos Marighella, considerando ambos grandes fomentadores do "terrorismo" em São Paulo. ${ }^{33}$ Essa imagem só não coincide com a posição crítica de Gorender com relação às estratégias equivocadas de guerrilha urbana proposta por Marighella. Em depoimento prestado no DEOPS/SP em 28 de janeiro de 1970, Gorender identifica no "terrorismo" uma das causas do afastamento das massas do movimento revolucionário. Para ele, a "Teoria do Foco" sempre foi insuficiente como estratégia revolucionária para a América Latina:

32 Os codinomes, Weber, Fernandes, Sabino e Cláudio foram adotados por Gorender para se proteger da polícia durante a vida na clandestinidade, envolvendo documentos de identificação falsos e deslocamentos sucessivos entre os Estados, cidades e bairros. Processo no.. 11 e 517 - Acervo BNM.

33 Relatório confidencial, intitulado "Os Problemas da Subversão no Brasil", para fins de uso exclusivo de autoridades militares federais e estaduais foi elaborado pelo Serviço Secreto/DOPS/SP buscando conhecer a posição das "Forças de Extrema Esquerda" de 1962-1968. Trata da atuação repressiva da Comunidade de Informação e Segurança anterior ao período Médici. O semanário O Movimento teve sua edição de $n^{\circ}$ 317, de $27 / 07$ a 02/08/1981 apreendida por noticiar com destaque a matéria: "O DOPS e a Esquerda", informando que o Jornal Em Tempo divulgou com exclusividade um relatório secreto do DOPS sobre a esquerda sob o título "Os Problemas da Subversão no Brasil". Fundo DEOPS/SP/Série Dossiês. Pasta n ${ }^{\circ} 50 \_$B-58-3122. 
Em setembro de 1967, vi-me desligado do PCB, e à míngua de recursos para viver e sustentar minha família. [...] Mantinha contato com JOAQUIM CÂMARA FERREIRA, e através dele, algumas vezes, estive com MÁRIO ALVES, quando este vinha a S. Paulo. Dessa maneira, continuei inteirado do desenvolvimento do processo em curso entre os dissidentes do PCB. Discordei, assim, da posição de JOAQUIM CÂMARA FERREIRA e CARLOS MARIGHELLA, ao qual vi, pela última vez, em março de 1967. Isto porque, para ambos, tudo se resumia no desencadeamento imediato da GUERRILHA URBANA e RURAL. Sendo embora admirador de ERNESTO CHE GUEVARA, como continuo a sê-lo, tanto quanto se refere à figura de combatente revolucionário, nunca aceitei a chamada "Teoria do Foco", que é associada ao seu nome e que tem, talvez, sua melhor expressão literária na obra "REVOLUÇÃO NA REVOLUÇÃO", de Regis Debray. Ao meu ver, a morte de Guevara assinala a morte da "Teoria do Foco". Não via, então, porque insistir em aplicá-la ao Brasil. [...]. Fui, por isso, ao RIO, em abril de 1968, onde tomei parte da fundação [...] do PCBR. Nesta mesma reunião, a discussão girou, no essencial, em torno da concepção da Revolução desdobrada nas etapas popular e socialista, bem como o caráter específico de cada uma dessas etapas. [...] Voltei a São Paulo e continuei a ganhar a vida como tradutor. Em julho de 1968, voltei ao RIO. [....] Ali se discutiu e aprovou uma resolução política, na qual, inclusive por grande empenho meu, se inseriu uma condenação formal dos métodos terroristas, que já estavam sendo empregados em S. Paulo. Considero que o Terrorismo cria para as Esquerdas uma imagem prejudicial diante das massas, que afasta essas últimas e nelas infunde uma atitude de passividade, finalmente facilitando, o que não é o menos importante, a ação repressora policial. Minha posição, nessa questão, é a de LÊNIN, conforme exposta em sua obra "QUE FAZER. ${ }^{34}$

No livro Combate nas Trevas, Gorender expõe suas divergências com a teoria foquista e com os pressupostos de guerrilha urbana e rural que sustentavam várias tendências que optaram pela luta armada imediata nos anos sessenta. Considera Marighella o homem mais valente que conhecera, mas este não seguiu as recomendações de Che Guevara. Refere-se à advertência de Guevara sobre os riscos do "terrorismo de esquerda", caracterizado pelo emprego de violência nas ações sem mensurar ao certo o impacto sobre a população. No Minimanual do Guerrilheiro Urbano (1969), Marighella introduz modificações na teoria cubana em voga: a guerrilha urbana se torna um instrumento primordial a nível tático, dando suporte a guerrilha rural. No entanto, Gorender acredita que continuou prevalecendo a concepção foquista na ALN, mantendo a concepção de vanguarda política e a ideia de que a guerrilha começa do zero, sem o necessário apoio das massas.

A sua fidelidade partidária ao PCBR, não impediu uma reflexão crítica e recusa à luta armada imediata. Passou a defender uma aproximação paulatina do partido com as massas, mas essa era um posição minoritária no interior do partido, acusado por outras organizações de estar atrasado nas suas ações. A luta interna deixou explícitas as divergências entre Mário Alves, defensor da luta armada, e Apolônio de Carvalho, que

34 DAESP/Fundo DEOPS/Série Dossiês. Pasta 30-C-1-18890. 
considerava imprudente tal precipitação. Gorender, ao dar razão para Apolônio, divergiu pela primeira vez do amigo Mário Alves. De forma lastimável, diz ele, o PCBR acabou comprometido com a luta armada, realizando ações como assaltos a bancos, sequestros, entre outras.

O desbaratamento da organização ocorreu por volta de 1969, com a prisão de vários militantes, incluindo o próprio Gorender. Mário Alves, assassinado nas câmaras de tortura, permaneceu com o nome na lista dos "desaparecidos" por muitos anos, indicando que nunca fora preso pela polícia política da Ditadura. Contudo, a pressão dos familiares corroborou para que o caso fosse esclarecido. Durante a vida clandestina, Gorender participou do modesto núcleo do PCBR em São Paulo A morte de Carlos Marighella o convenceu em definitivo da enorme sangria das organizações de esquerda armada, cessando assaltos e sequestros na tentativa de evitar um desastre maior do movimento revolucionário. Nos seus variados escritos e depoimentos encontrados nas fontes de natureza repressiva, o historiador afirma que em 1964, defendeu a revolução comunista de caráter pacífico. Após esta data, a convicção de uma revolução nacional libertadora foi substituída pela crença na revolução armada com o apoio das massas.

O longo passado comunista e a militância no PCBR em finais dos anos sessenta acenderam os tentáculos da repressão. Algemado pelos homens do Esquadrão da Morte sob a chefia do Delegado Sérgio Paranhos Fleury, seguiu para o terceiro andar do DEOPS, local em que foi barbaramente torturado, justamente no dia em que completava 47 anos. A lembrança da data do aniversário surgiu pelo comentário sarcástico de um dos tiras. Seu depoimento é acompanhado de uma advertência que afasta qualquer pretensão de apresentar-se como herói de resistência à ditadura. Para não cair nessa armadilha, avisa ao leitor que o seu relato não exclui momentos de maior desespero e angústia. No entanto, busca o sentido coletivo dessa luta, dando voz aos que sobreviveram à tortura e aos mortos, notadamente Mário Alves.

Narra que desde 1942, sempre leu e ouviu inúmeros relatos sobre torturas, verificando que parte dessa literatura "exalta os heróis vencedores da provação imposta pelo inimigo" (GORENDER,1987:215). Dessa maneira, o militante comunista vai interiorizando uma norma moral que deve fortalecê-lo nas situações de tortura. Alguns escritos de Marighella, datado de 1936, são exemplos dessa preparação para o enfrentamento do militante com a situação de tortura. O depoimento trágico e ao mesmo tempo belo provoca no leitor a repulsa à tirania e a condenação do arbítrio:

A função começou por uma dose de choques elétricos. A intervalos, novas doses. $O$ delegado Ivair distribuía instruções com profissionalismo. Vez por outra, reclamava do exagero do serviço. Mas o serviço prosseguia. Depois de pontapés e telefones (tapas atordoantes, 
e simultâneos nos dois ouvidos), [...] chegou a vez do pau-de-arara. [...] De pés e mãos atados por cordas, seguro à trave de face para cima, eu ia recebendo choques elétricos em várias partes do corpo, queimaduras na planta dos pés, telefones. A água derramada sobre o corpo aumentava o efeito da eletricidade. Fizeram o afogamento: introdução de água pelas narinas por meio de um funil. Com a cabeça inclinada para baixo, a água entope o nariz, sai pela boca e provoca sensação de asfixia. Atento a meu nível de resistência, Ivair ordenava interrupções e eu era depositado no chão, continuando com a trave no meio dos pés e mãos atadas. Repetiam-se as perguntas e ameaças. Terminado o intervalo, novamente me alçavam no pau-de-arara.

Creio que depois de seis horas de tortura, lá pelas três da madrugada, suspenderam a função e mandaram que me vestisse. O corpo muito dolorido, caminhei com dificuldade até largo recinto. Indicaram uma confortável poltrona para me acomodar [...]. O resto da noite ia ser empregado na pressão psicológica. [...]. Tudo vil e nojento. [...] Quando saí da escuridão, me vi sentado de novo na poltrona, dos pulsos abertos vazava sangue. [...] um enfermeiro fez curativos nos ferimentos e estancou a hemorragia. [...] Ás sete da manhã, introduziram-me na carceragem [...]. Fecharam-me na cela solitária do fundão e só vieram me buscar pouco depois de uma hora da tarde, [...] onde me puseram diante do próprio Fleury. [...], disse em tom frio: - Você é meu prisioneiro. Deram-me uma cadeira para sentar e, pouco depois, veio um médico. [...] Feito o exame sumário, disse a Fleury [...]. Ele está bem. [...] Passados vários dias, resolveram encerrar a tortura e fui entregue às mãos de Luís Apolônio, a fim de prestar depoimento tomado a termo por escrito. [...] Prestei o depoimento da fase policial em condições de aguda debilitação física e num ambiente de terror onipresente. Duelava contra um inquisidor habilidoso. [...] Depois de mês e meio, tiraram-me da solitária do fundão e me colocaram numa cela coletiva. A próxima fase seria no Presídio Tiradentes. [...] O Presídio Tiradentes significava proteção judicial, uma vez que só então a detenção deixava de ser sigilosa e incomunicável e se formalizava na Auditoria Militar (GORENDER, 1987, p.218-219).

Em entrevista concedida ao jornalista Alípio Freire e Paulo de Tarso Venceslau, ${ }^{35}$ Gorender declarou que tentou suicídio após ser submetido a longas sessões de tortura e justifica seu ato de coragem, como a de qualquer cidadão que estivesse submetido a força brutal dos torturadores. Os agentes da repressão optavam por manter vivos os seus prisioneiros, sugando deles todas as informações sobre as organizações e seus militantes. A morte, provocada pelo preso, poderia significar uma "derrota", trabalho não concluído dos torturadores. Em suma, o suicídio era tomado como afronta ao sistema repressivo:

Ali eu fui submetido à tortura e tentei o suicídio. Não tenho, a respeito disso, questionamentos de ordem moral. Houve outros companheiros

\footnotetext{
35 Entrevista publicada na revista Teoria \& Debate $n{ }^{\circ} 11$, 30. trimestre de 1990 e reeditada no livro Rememória: Entrevistas sobre o Brasil do século XX. São Paulo, Ed. Perseu Abramo, 1997. Também publicada em 09/04/2006 http://www2.fpa.org.br/. Memória: Jacob Gorender - O PCB, a FEB e o marxismo. Teoria e Debate $n^{\circ} 11$ julho/agosto/setembro de 1990. Acesso em 19/09/2012.
} 
que tentaram suicídio e alguns o consumaram. No movimento revolucionário internacional, é norma que o militante deve resistir às torturas para não entregar informações ao inimigo, mas ele não está obrigado a sofrimentos evitáveis. (AZEVEDO; MAUÉS,1997:198).

Gorender permaneceu um mês e meio sob tortura na sede do DEOPS em São Paulo. Logo depois, transferido para o Presídio Tiradentes, conviveu com vários presos políticos durante um ano e meio e atuou fortemente para que os seus direitos fossem respeitados. O cotidiano dos que estiveram presos e ousaram denunciar as torturas foram marcadas na Carta encaminhada ao XIII Congresso Nacional dos Jornalistas Profissionais, realizado em Salvador em 1970. O documento atesta a coragem dos presos políticos, entre eles Jacob Gorender, que solicitaram inspeção da Cruz Vermelha Internacional para averiguações do emprego da tortura e outros tipos de violências cometidas nos presídios brasileiros. Também enumeram ilegalidades e arbitrariedades cometidas na esfera do judiciário ao tratar dos processos de presos políticos:

[...] 2)Indiciados em inquéritos, chegam a esperar mais de um ano para serem denunciados, e, iniciadas as audiências de interrogatório - estas são logo interrompidas - sem que todos os réus do processo sejam ouvidos - para que novos processos tenham andamento para logo serem, por sua vez, suspensos. É evidente o objetivo protelatório de tais manobras, bem como sua manifesta ilegalidade. 3)Toda e qualquer petição encaminhada pelos advogados, [...] são engavetadas;4) As ilegalidades, [...] das autoridades judiciárias antecedem a fase do processo. A começar pela prisão, que, quando não se reveste de verdadeira tentativa de execução sumária, apresenta as características de seqüestro. Isto com afronta pública, pois são vários os casos de espancamento em plena rua, com ofensas e não rara detenção de familiares das vítimas. Houve casos de crianças serem detidas com seus pais e encarceradas nos xadrezes da OBAN [...] gritos aterrorizados de seus pais nas sessões de torturas. (Trecho da Carta encaminhada ao XIII Congresso Nacional dos Jornalistas Profissionais, 1970).

No livro Combate nas Trevas, o historiador afirma que os presos sabiam de antemão que a carta não seria encaminhada. De fato, ela foi arquivada pelos agentes do DOPS. No entanto, os presos políticos ganharam cobertura legal no caso de acusações contra atos "subversivos". Por caminhos "misteriosos", diz Gorender, a cópia da carta saiu do presídio e chegou ao exterior. O Relatório da Anistia Internacional de 1972 reproduziu longo trecho da carta dos jornalistas brasileiros, denunciando a existência da tortura no país. Ainda, o episódio da carta encontra-se narrado no livro de Gorender que avaliou da seguinte maneira as conseqüências para os presos do Presídio Tiradentes: "Ao computar no passivo da operação: o confisco da única máquina de escrever permitida numa das celas” (GORENDER,1987, p.223). 
Documentos anexados aos Processos n. ${ }^{\circ} 11$ e n. ${ }^{\circ}$ 517, além de referenciar o denunciado Jacob Gorender, comprometem a sua esposa, Idealina da Silva Fernandes que militou no PCB entre os anos de 1945 e $1946 .{ }^{36}$ Deixou o Rio de Janeiro em 1967 rumo a cidade de São Paulo para viver com Gorender, ocasião em que falsificou sua identidade, passando a se chamar Odete Ferreira Almeida. "A falsidade de identidade da denunciada, aliada aos seus antecedentes constitui grave indício de sua participação nos atos criminosos atribuídos ao seu amásio Jacob Gorender". ${ }^{37}$ Nas declarações de Idealina no DEOPS/SP, 18/2/1970, admitiu para os seus interrogadores que utilizou o documento falso para conseguir um emprego na Editora Abril, assinando a tradução de textos em francês e italiano, que na realidade eram traduzidos por Jacob Gorender. O episódio narrado demonstra a luta cotidiana e os riscos enfrentados pelos militantes comunistas e familiares para garantir a sobrevivência na clandestinidade:

Conseguiu manter uma entrevista com o Sr. Pedro Paulo, a quem disse ser tradutora do francês e italiano e desejava serviços de tradução, sem dizer e nem pronunciar o nome de Jacob Gorender que, até hoje, é ignorado naquela firma, pois esta pensa que a tradutora é, realmente, a interrogada; que o Sr. Pedro Paulo disse a interrogada que precisava fazer um teste antes de ser admitida, e isto deixou um tanto confusa a interrogada, mas depois quando soube que esse teste poderia ser feito em casa, acalmou-se, pois Jacob foi quem o desenvolveu; desta forma, após levar a Editora o teste, foi ela aceita; que, assim, a interrogada passou a freqüentar os escritórios da Editora até que recebeu os primeiros trabalhos. ${ }^{38}$

No livro Combate nas Trevas, Gorender confirma o depoimento de Idealina sobre a realização do trabalho como tradutor em São Paulo em tempos de clandestinidade. Adverte também para a sua recusa em sair do país e viver como exilado político.

Do ponto de vista pessoal, não tomei parte em nenhuma ação armada [...]. Na incerteza crescente da clandestinidade, sobrevivi penosamente com o trabalho de tradutor. [...] Nunca me passou pela cabeça a opção de

36 A seguir trecho da entrevista de Gorender de 1990: "Nessa sua trajetória toda, como foi o relacionamento com a sua família e a sua companheira? A minha companheira, Idealina, com quem convivo há mais de 30 anos, foi militante do PCB. Eu a conheci aqui no Brasil, mas, sobretudo quando fazíamos o curso lá em Moscou. Minha companheira é parte inseparável dessa vida e me sustentou nos momentos mais difíceis. Para mim, também é uma grande satisfação que minha filha tenha desenvolvido uma forte personalidade, que pense pela própria cabeça, sem que isso dê lugar, entre nós, a conflitos ideológicos e políticos. O pai de Idealina foi um operário eletricista e é um dos nove fundadores do PCB. Figura naquela foto histórica na qual também está o Astrojildo Pereira." Reeditada por Azevedo e Mauès (1997, p. 202).

37 Jacob Gorender, Idealina da Silva Fernandes, Aytan Miranda Sipahi, Erki Juhant Larsson, Adilson Odair Citelli, Valdizar Pinto do Carmo, Sérgio Sister e Pura Lopez Cortez foram qualificados nos Autos como incursos nas sanções dos arts. 43, 45, I, do DL 898 de 29.9.1969, conforme fatos delituosos expostos pela denúncia encaminhada pelo Procurador Durval A Moura de Araújo ao Sr. Dr. Juiz Auditor da $2^{\text {a }}$ Auditoria da $2^{\text {a }}$ R. M. em 17/4/1970. 38 Relatório dos Indiciados elaborado pelo DOPS/SP, em 9 de março de 1970. 
sair do País à procura de refúgio no exterior. Para ter razão eu precisava fincar pé no Brasil e pagar o mesmo preço que os companheiros estavam pagando" (GORENDER, 1987, p.216).

Os fragmentos dos inquéritos e declarações anexados aos processos do casal revelam a complexa trama jurídica que justificou prisões, torturas e julgamentos com penas a cumprir. Os presos políticos pertenciam a diferentes grupos políticos e sociais, submetidos ao aparato jurídico que, naquele momento histórico, esteve a serviço dos interesses do poder militar. A orientação era capturar, a qualquer custo, o "inimigo interno", o que se justificava pelo acirramento da Guerra Fria. A Justiça transcendeu as normas da dignidade humana, submetida que estava a uma ditadura marcada pela violência e arbítrio contra os direitos humanos.

\section{Considerações Finais}

A Justiça foi o palco de enraizamento dos conflitos políticos e sociais, lugar de tensões e articulações de uma trama histórica envolvendo vítimas e algozes, militares e civis. O espaço jurídico garantiu uma espécie de legitimidade ancorada nos testemunhos e em documentos, forjados ou não, pretendendo, ao final, representar também uma determinada verdade dos fatos.

Analisamos os Dossiês referentes ao historiador preparados pelo DOPS e os Processos da Justiça Militar, destacando acontecimentos representativos para uma compreensão mais ampla da história das esquerdas no Brasil. O caso da Caderneta Prestes, por exemplo, foi emblemático do ponto de vista das contradições, do emaranhando de intrigas, subordinando o emprego de graus variados de violência política, dependendo do perfil dos acusados. A ruptura de Gorender com o PCB, Partido Comunista Brasileiro em 1967, e a formação do PCBR, Partido Comunista Brasileiro Revolucionário em 1968, constituiu também um forte atrativo na investigação empreendida por eles.

Além dos fatos marcadamente políticos, os dados e versões produzidas pelos órgãos repressivos permitiram identificar o grau de vigilância que se abateu sobre seus familiares, companheiros de partidos e anônimos. Apontam também para as estratégias de sobrevivência na clandestinidade e os duros momentos vividos na prisão. No espaço prisional, Gorender sobreviveu à tortura, ministrou cursos de formação política e histórica, participou e organizou greves de fome, elaborou, em conjunto com outros companheiros, cartas-denúncias remetidas ao exterior, contribuindo com a luta dos exilados. O material arquivado revela também que o historiador obteve uma liberdade vigiada após 1971. Ao 
longo das décadas de setenta e oitenta suas atividades acadêmicas e políticas foram seguidas e registradas pelos agentes do DOPS, revelando o prolongamento do cerco repressivo.

Ao confrontar a ditadura militar, cada um vivenciou a sua maneira, a violência do opressor. Jacob Gorender experimentou a dinâmica de uma máquina repressora que através de decisões e ações nos estados, conservou uma relativa autonomia com relação ao poder federal. Absolvido pelo Tribunal Militar em 1971, após um ano e meio de cumprimento de pena, buscou sempre desafiar a ditadura. Como sobrevivente recuperou identidades perdidas no tempo, especialmente com escritos mais polêmicos de teor memorialístico e historiográfico. Jacob Gorender representa a voz da denúncia, porta-voz de uma memória que exige do Estado não somente o direito à verdade e à justiça nos limites de uma democracia liberal burguesa, mas um homem que continua apostando na capacidade de transformação de nossa sociedade. Portanto, cabia silenciar essa voz, mas não ao ponto de uma eliminação física completa. A admiração pelo grande intelectual como parte de uma internacional comunista de pensamento e o respeito por sua passagem pela FEB durante a II Guerra Mundial impuseram limites aos seus algozes, garantindo após as terríveis sessões de tortura, a sobrevivência do historiador.

\section{Fontes}

ACERVO DEOPS. Fundo DEOPS/SP/Série Dossiês e Prontuários. Divisão do Arquivo do Estado de São Paulo) - 141 Pastas referentes ao historiador Jacob Gorender.

PROCESSOS: Justiça Militar. Projeto Brasil Nunca Mais. Campinas: UNICAMP/IF.

Documentário: Memórias de Jacob Gorender - A Esquerda Revelada. Realizado pela TV Câmara para a série Memórias. Parceria com o Departamento de História da UnB. Direção de Glória Varela. Lançado em 8/10/2009.

\section{Referências}

AZEVEDO, Ricardo de; MAUÉS, Flamarion. (Org.). Entrevista com Jacob Gorender. In: . Rememória: entrevistas sobre o Brasil do século XX. São Paulo: Fundação Perseu Abramo, 1997. p. 173-203. (Coletânea de Depoimentos).

GORENDER, Jacob. Entrevista para o Programa Memória Roda Viva. Realização Fundação Padre Anchieta, Labjor/Unicamp - Nepp/Unicamp, 2006. 
GORENDER, Jacob. Combate nas trevas: a esquerda brasileira: das ilusões perdidas à luta armada. São Paulo: Ática, 1987.

GORENDER, Jacob. Entrevista. Por José Corrêa Leite. Revista Teoria e Debate, São Paulo, n. 43, jan./mar. 13 mar. 2000. Disponível em:<www2.fpa.org.br>. Acesso em: 13 abr. 2009.

GORENDER, Jacob. Entrevista. Projeto Memória do Movimento Estudantil. Por Ana Paula Goulart e Angélica Muller. 15 jun. 2005. Disponível em:<www.memoriaestudantil.org.br>. Acesso em: 13 abr. 2009.

GORENDER, Jacob. Era o golpe de 64 inevitável? In: TOLEDO, Caio Navarro de (Org.). 1964: visões críticas do golpe: democracia e reforma no populismo. Campinas: UNICAMP, 1997.

VILLAMÉA, Luiza. De braço dado com o inimigo. Nova edição de Combate nas Trevas relata proposta de aliança feita, em 1969, por general de linha-dura ao guerrilheiro Marighella. Isto É, São Paulo, 6 maio 1998. Disponível em: <www.terra.com.br/istoé/política/149227.htm>. Acesso em: 13 abr. 2009. 